\title{
LABOUR FORCE IN POLISH RURAL AREAS AFTER POLAND'S ACCESSION TO THE EUROPEAN UNION
}

\author{
Wlodzimierz Kolodziejczak ${ }^{1}$, Ph.D. \\ ${ }^{1}$ Poznan University of Life Sciences, Department of Finance and Accounting
}

\begin{abstract}
The size and usage level of labour resources co-determine the economic potential and strength. The above aspect is particularly important in Polish rural areas, which remain affected by side effects of the economic transformation. The purpose of this paper is to analyse the evolution of the size and usage levels of labour resources related to Polish rural areas after Poland's accession to the EU, compared to earlier figures. The subject matter of this study is labour resources in Polish rural areas seen in the context of demographic trends and economic developments over the 2002-2050 period. Polish rural areas have a significant population potential and strong labour resources. Over time, their potential will become increasingly important for the entire country, especially considering the progressing urban depopulation. Later in the study period, the population's professional situation was steadily improving on a year-to-year basis. This was reflected by the consistent increase of the economic activity rate and employment rate, and by the declining unemployment rate.
\end{abstract}

Key words: labour force, rural areas, rural population, economic activity of the population, EU accession. JEL code: J21, J11.

\section{Introduction}

The size and usage level of labour resources co-determine the economic potential and strength. In addition to land and capital, labour is one of the three classic productive inputs. Therefore, what matters for economic growth and development is the size as well as the quality and usage level of labour resources. That problem becomes particularly important in less developed areas, which often remain affected by side effects of the economic transformation and by the resulting surplus of unused labour resources: the unemployed, inactive and inefficient employees (which means those formally employed whose labour fails to provide economic benefits: this situation is referred to as 'hidden unemployment').

Polish countryside is one of these areas. This results from the historical background, which is different from any other European country. Polish rural areas continue to be adversely affected by the fragmentation of farmland and by the absorption of overstaffing originating from nonagricultural sectors. The rural population is less educated than their urban peers; and the distance from economic and industrial centres makes it difficult for them to compete in the non-agricultural labour market (Kolodziejczak and Wysocki, 2015). Therefore, the agriculture sector remains the primary employer for the Polish rural population. Another difference between Polish and other European rural areas is the important size of labour resources.

The purpose of this paper is to analyse the evolution of the size and usage levels of labour resources related to Polish rural areas after Poland's accession to the EU, compared to earlier figures.

The analysis was based on data from the Central Statistical Office of the Republic of Poland, the EUROSTAT database and the relevant literature. The subject matter of this study is labour resources in Polish rural areas seen in the context of demographic trends and economic developments. The study period extends from 2002 to 2050.

\section{Research results and discussion}

In Poland, 1989 marked the start of dynamic structural changes to the economy, which particularly impacted the agricultural sector. At the same time, the demographic and social 
situation was also changing. New labour resources started to emerge in the market (as the 1980s baby-boomers reached the age of economic activity). That process coincided with a considerable reduction of jobs on a countrywide basis. It resulted in a wave of redundancies and professional deactivation while making it difficult to find a job for the most disadvantaged population: young inexperienced persons living outside the largest cities and those approaching retirement (Socha i Sztanderska, 2002; Tyrowicz, 2011; Sobolewska-Wegrzyn, 2012; Karwat-Wozniak and Chmielinski, 2013; Kolodziejczak and Wysocki, 2015). The unused surplus of labour was deactivated with institutional tools (early retirement, bridging programs for the elderly, especially those employed in mining and industry). Also, the young population was encouraged to continue their education rather than look for a job. Those who could not be permanently or temporarily deactivated as described above remained unemployed after losing their jobs. Because the number of jobs either decreased or grew slowly, structural unemployment became the dominating type of unemployment. This was an almost insurmountable obstacle, decreasing slightly in periods of higher GDP growth and growing over economic downturn periods (Socha and Sztanderska, 2002). Having lost their jobs due to winding-up of restructured industrial plants, some of the rural population who had migrated to cities in the 1970 s and 1980s returned to their family farms located in rural areas. This exacerbated the pre-existing overstaffing of individual farms while strengthening their social function (Kolodziejczak and Wysocki, 2015).

From 2000 until Poland's accession to the EU in 2004, the labour market was in the worst condition since the early 1990s. High open unemployment, low economic activity rates and high surpluses of inefficient employment in the agricultural sector were the factors that slowed down the economy while perpetuating the structural nature of labour market disadvantages. By joining the EU in 2004, Poland became eligible for aid under structural programmes. Also, the accession enabled a growth of exports and helped attracting foreign investors (Pawlak et al., 2015). The Western European labour markets became progressively available to Polish employees and absorbed a large part of labour surplus. The employment of Polish citizens in foreign countries was a relief for the national labour market, enabling an increase in the households' incomes. However, those who found jobs abroad were young, mobile and skilled persons which, in turn, resulted in difficulties to hire employees in some industries. While the opening up of frontiers had a considerable impact on unemployment figures, it failed to remove its core component: the structural unemployment. The next years open a new perspective for the analysis of labour resources and labour market. New problems emerge because of the forecasted population reduction and ageing. In the long run, the key thing is no longer to use the surplus labour but rather to look for ways to offset the shortfalls in labour (Kolodziejczak and Wysocki, 2015).

The rural population has always had a significant (though varying over time) share in the Polish population. In 1946, the rural population was a majority, with a share of $68.2 \%$ in the total Polish population (Table 1). In 2002, it was the opposite: the rural population had a share of $38.2 \%$ in the total country's population. In 1946-2002, the Polish population grew by $59.8 \%$, from 23930000 to 38.230.000. Over that period, the rural population decreased by 1489000 (9.2\%). However, in 2017, the rural population (15 317 000) was greater than in 2002 and represented $39.9 \%$ of the total national population. As forecasted by the Central Statistical Office, the Polish population will reduce by 1892000 over the 2017-2035 period. This will be particularly noticeable in urban areas, which will lose 2107000 inhabitants $(9.1 \%)$. Over that period, the rural population will grow by $127000(0.8 \%)$ to represent $42.3 \%$ of the national population. In 
the next period, by 2050, the Polish population will reduce by 4418000 compared to 2017 ( $11.5 \%$ of the 2017 population). The depopulation will mainly affect the cities, which will lose 4226000 inhabitants (18.2\%), compared to a population loss of barely $192000(1.3 \%)$ in rural areas. In 2050, $44.5 \%$ of the Polish population will live in rural areas; because of a higher fertility rate, the rural population will be younger and more mobile than urban residents (Population projection, 2014). Therefore, it should be concluded that Polish rural areas demonstrate a high population potential, which means large labour resources. Over time, their potential will become increasingly important for the entire country, especially considering the progressing urban depopulation.

Table 1

\section{Share of the rural and urban population (thousand) in the total Polish population in 1946, 2002, 2017 and 2035}

\begin{tabular}{|c|c|c|c|c|c|}
\hline \multirow{2}{*}{ Year } & \multirow{2}{*}{ Total } & \multicolumn{2}{|c|}{ Urban areas } & \multicolumn{2}{c|}{ Rural areas } \\
\cline { 3 - 6 } & & in thousands & \% & in thousands & \% \\
\hline $\mathbf{1 9 4 6}$ & 23626 & 7517 & 31.8 & 16109 & 68.2 \\
\hline $\mathbf{2 0 0 2}$ & 38230 & 23610 & 61.8 & 14620 & 38.2 \\
\hline $\mathbf{2 0 1 7}$ & 38369 & 23052 & 60.1 & 15317 & 39.9 \\
\hline $\mathbf{2 0 3 5}$ & 36477 & 20945 & 57.4 & 15444 & 42.6 \\
\hline $\mathbf{2 0 5 0}$ & 33951 & 18826 & 55.5 & 15125 & 44.5 \\
\hline
\end{tabular}

${ }^{a}$ As regards the shares of the urban and rural population, the 1946 census failed to take account of 304.000 individuals (Statistical Yearbook of the Republic of Poland, 2003).

Source: author's study based on Statistical Yearbook of the Republic of Poland (2003); Population projection 2008-2035 (2007); Population projection 2014-2050 (2014)

Table 2 shows the characteristics of the population aged 15 or more, i.e. individuals included in actual (economically active) and potential (economically inactive) labour resources'. What should be noted first, is the fact that the size of this group decreases in urban areas while growing in rural areas, as a natural consequence of demographic trends presented in Table 1. Throughout the 2002-2016 period, the reasons for these developments were the higher demographic growth rate in rural areas compared to cities, and the increasingly noticeable suburbanization of areas located next to big urban centres. Thus, the general growth of the rural population did not mean the perpetuation of a typically rural and agricultural nature of these areas. Neither did it protect the country's poorest and remotest territories against depopulation. Note also that because of suburbanization, some of the rural residents are commuters professionally linked to cities. For them, rural areas mean a place of residence where they can find peace and better quality of living than in cities they migrated from (Kajdanek, 2011).

In the initial years of the study period, the economy was still severely affected by the reduction of jobs due to economic transformation and restructuring of many activities, primarily including the industry, mining and state-owned agricultural land. Later, the urban and rural population's professional situation was steadily improving. This was reflected by the consistent increase of the economic activity rate and employment rate, and by the declining unemployment rate (Table 2). The economically inactive population was declining in urban areas while slightly growing in rural areas. Poland's accession to the Table 2

\footnotetext{
1 The relevant literature usually assumes that the economically active population represent the labour resources while the inactive population remain outside these resources (Begg et al., 1992). When adopting a slightly different approach, it may be assumed that the economically active population are the active labour resources while the inactive population are inactive (potential) resources (which, however, could become active under specific are the active labour resources while the inactive population are inactive (potential) resources (which, however, could become active under specific
circumstances) (Kolodziejczak and Wysocki 2015). Also, the group of potential labour resources could be identified which consists of unemployed and circumstances) (Kolodziejczak and Wysocki 2015). Also, the group of potential labour resources could be identified which consists
economically inactive people. In turn, Krynska (2006) defines potential labour resources as the entire working-age population.
} 
Economic activity of the population aged 15 and more by sex and place of residence in the years 2002-2017

\begin{tabular}{|c|c|c|c|c|c|c|c|c|c|c|}
\hline \multirow{4}{*}{$\begin{array}{c}\text { Speci- } \\
\text { fica- } \\
\text { tion }\end{array}$} & \multirow{4}{*}{ Total } & \multicolumn{5}{|c|}{ Economically active population } & \multirow{4}{*}{$\begin{array}{c}\text { Eco- } \\
\text { nomi- } \\
\text { cally } \\
\text { inac- } \\
\text { tive } \\
\text { per- } \\
\text { sons }\end{array}$} & \multirow{4}{*}{$\begin{array}{l}\text { Activi- } \\
\text { ty rate }\end{array}$} & \multirow{4}{*}{$\begin{array}{l}\text { Em- } \\
\text { ploy- } \\
\text { ment } \\
\text { rate }\end{array}$} & \multirow{4}{*}{$\begin{array}{c}\text { Unem- } \\
\text { ploy- } \\
\text { ment } \\
\text { rate }\end{array}$} \\
\hline & & \multirow{3}{*}{ total } & \multicolumn{3}{|c|}{ employed persons } & \multirow{3}{*}{$\begin{array}{c}\text { Unem- } \\
\text { ployed } \\
\text { per- } \\
\text { sons }\end{array}$} & & & & \\
\hline & & & \multirow[b]{2}{*}{ total } & \multicolumn{2}{|c|}{ working } & & & & & \\
\hline & & & & $\begin{array}{l}\text { full- } \\
\text { time }\end{array}$ & $\begin{array}{l}\text { part- } \\
\text { time }\end{array}$ & & & & & \\
\hline \multicolumn{11}{|c|}{ Urban areas } \\
\hline 2002 & 19537 & 10711 & 8432 & 7734 & 698 & 2279 & 8826 & 54.8 & 43.2 & 21.3 \\
\hline 2003 & 19479 & 10545 & 8353 & 7695 & 658 & 2191 & 8934 & 54.1 & 42.9 & 20.8 \\
\hline 2004 & 19540 & 10544 & 8453 & 7763 & 690 & 2090 & 8996 & 54.0 & 43.3 & 19.8 \\
\hline 2005 & 19586 & 10621 & 8632 & 7925 & 707 & 1989 & 8965 & 54.2 & 44.1 & 18.7 \\
\hline 2006 & 19587 & 10471 & 8964 & 8279 & 685 & 1507 & 9116 & 53.5 & 45.8 & 14.4 \\
\hline 2007 & 19554 & 10445 & 9416 & 8723 & 694 & 1029 & 9109 & 53.4 & 48.2 & 9.9 \\
\hline 2008 & 19506 & 10546 & 9788 & 9093 & 695 & 758 & 8960 & 54.1 & 50.2 & 7.2 \\
\hline 2009 & 19516 & 10689 & 9803 & 9083 & 721 & 885 & 8827 & 54.8 & 50.2 & 8.3 \\
\hline 2010 & 19103 & 10549 & 9503 & 8780 & 724 & 1046 & 8555 & 55.2 & 49.7 & 9.9 \\
\hline 2011 & 19046 & 10561 & 9534 & 8842 & 692 & 1026 & 8485 & 55.4 & 50.1 & 9.7 \\
\hline 2012 & 19001 & 10585 & 9527 & 8828 & 699 & 1058 & 8417 & 55.7 & 50.1 & 10.0 \\
\hline 2013 & 18941 & 10572 & 9487 & 8789 & 698 & 1085 & 8369 & 55.8 & 50.1 & 10.3 \\
\hline 2014 & 18853 & 10603 & 9682 & 8948 & 734 & 921 & 8251 & 56.2 & 51.4 & 8.7 \\
\hline 2015 & 18804 & 10578 & 9815 & 9096 & 719 & 763 & 8226 & 56.3 & 52.2 & 7.2 \\
\hline 2016 & 18538 & 10420 & 9803 & 9121 & 681 & 618 & 8117 & 56.2 & 52.9 & 5.9 \\
\hline \multicolumn{11}{|c|}{ Rural areas } \\
\hline 2002 & 11526 & 6502 & 5350 & 4564 & 786 & 1152 & 5024 & 56.4 & 46.4 & 17.8 \\
\hline 2003 & 11473 & 6401 & 5263 & 4494 & 769 & 1137 & 5073 & 55.8 & 45.9 & 17.8 \\
\hline 2004 & 11583 & 6481 & 5342 & 4538 & 804 & 1140 & 5102 & 56.0 & 46.1 & 17.6 \\
\hline 2005 & 11672 & 6540 & 5483 & 4669 & 814 & 1056 & 5132 & 56.0 & 47.0 & 16.1 \\
\hline 2006 & 11778 & 6467 & 5630 & 4890 & 739 & 837 & 5311 & 54.9 & 47.8 & 13.0 \\
\hline 2007 & 11838 & 6414 & 5824 & 5114 & 711 & 590 & 5424 & 54.2 & 49.2 & 9.2 \\
\hline 2008 & 11867 & 6465 & 6012 & 5365 & 647 & 453 & 5402 & 54.5 & 50.7 & 7.0 \\
\hline 2009 & 11945 & 6591 & 6065 & 5451 & 614 & 526 & 5354 & 55.2 & 50.8 & 8.0 \\
\hline 2010 & 11852 & 6575 & 5970 & 5394 & 576 & 605 & 5277 & 55.5 & 50.4 & 9.2 \\
\hline 2011 & 11957 & 6660 & 6028 & 5469 & 559 & 632 & 5297 & 55.7 & 50.4 & 9.5 \\
\hline 2012 & 12037 & 6755 & 6064 & 5528 & 536 & 692 & 5281 & 56.1 & 50.4 & 10.2 \\
\hline 2013 & 12096 & 6789 & 6081 & 5564 & 517 & 708 & 5307 & 56.1 & 50.3 & 10.4 \\
\hline 2014 & 12131 & 6826 & 6180 & 5680 & 500 & 646 & 5306 & 56.3 & 50.9 & 9.5 \\
\hline 2015 & 12159 & 6810 & 6269 & 5796 & 472 & 542 & 5348 & 56.0 & 51.6 & 8.0 \\
\hline 2016 & 12166 & 6840 & 6395 & 5926 & 468 & 446 & 5325 & 56.2 & 52.6 & 6.5 \\
\hline
\end{tabular}

The European Union in 2004 was the starting point for improvements in the labour market. What also should be noted is the gradual equalization of the economic activity rates and employment rates in urban and rural areas. At the beginning of the study period, the rural population was characterized by slightly higher economic activity rates. However, as time went by, in line with improving economic situation and in relation to the gradual reduction of inefficient employment in the agriculture, that difference (which was 2.4 percentage points in 2002) was brought down to zero. The same is true for the employment rate: initially, the level recorded in rural areas was by 3.2 percentage points higher compared to urban areas; but afterwards, 
conversely, the urban employment rate was by 0.3 percentage points higher than the level recorded in rural areas. The matter of major importance for the growth of employment and reduction of unemployment was the growing number of jobs resulting from economic development. The 2003-2005 period marked the beginning of improvements to employment figures, which is seemingly related to the economic recovery that accompanied Poland's accession to the EU. In parallel, economic deactivation levels continued to follow a slight upward trend until 2008 (this was due to demographic factors and legislative measures, which allowed the employees to retire before regular retirement age). However, in 2009, the economic activity rate also started to grow, despite the parallel increase of the population's average age (Kolodziejczak and Wysocki, 2015).

One of the major problems affecting the rural labour resources is the excessive employment in agriculture (Frenkel, 2003; Kolodziejczak, 2011; Frenkel, 2013). In Poland, the share of agricultural employees in the total population employed in the national economy was $11.5 \%$ in 2014, which is more than twice as high as the EU-27 average level (5\%). As regards this ratio, worse results were reported only in Romania (29.4\%), Bulgaria (19.4\%) and Greece $(12.4 \%)$, with a comparable level recorded in Portugal (11.3\%). The historical background and the economic development level are of vital importance for the agricultural employment level. Other countries with the highest share of agricultural employees demonstrate a high share of mountainous terrains, which determined the natural development of farm structures. In Poland, the decisive factors were the traditional attachment to private land property and the economic transformation after 1989. However, what should be noted is the considerable reduction of employment in the Polish agriculture: in 2002, as much as $19.4 \%$ of the total employee population were agricultural employees (www.europa.eu, accessed on January 20, 2018).

Usually, the farming population demonstrated higher employment ratios and lower unemployment levels. Also, they were less vulnerable to economic deactivation than non-farmers (Table 3). Note, however, that a part of the farming population could stop their work with no detrimental effects on production outcomes. This means hidden unemployment, which tends to decrease over time as the number of non-agricultural jobs grows (Frenkel, 2003, Kolodziejczak, 2016). In 2002, with a share of $58.5 \%$, the farming population represented the majority of economically active rural residents (11.512.000). By 2017, that share decreased to $31.4 \%$ (3.826.000; by 27.1 percentage points) of the total farming population. This significantly impacted the professional situation of both the farming and non-farming population. As it may be noticed, in 2017, there was less non-farming unemployed and much more employed people than in 2002. This could primarily result from economic deactivation (in the study period, the economically inactive non-farming population increased by 2061000 individuals; this was largely caused by the impact of demographic factors and by the retirement of farmers). At the same time, the rural farming population improved their professional situation. In this group as well, the unemployment figures went down and (unlike in the non-farming population) so did the number of economically inactive individuals.

In the study period, women had a lower share in the employed group than men (Table 3). No considerable changes in this respect occurred between 2002 and 2016. The general improvement of the labour market situation on a countrywide basis enabled a clear increase of the number and share of employed persons. However, as regards women, economic inactivity continued to be the main problem. This could be partially explained by: the nature of farming work (men usually 
handle physically demanding tasks and operate the machinery); the option not to declare farming employment by women

Table 3

\section{Population aged 15 and more in rural areas by connection with agricultural farm, sex and economic activity}

\begin{tabular}{|c|c|c|c|c|c|c|c|c|c|}
\hline \multirow[t]{2}{*}{ Specification } & \multicolumn{3}{|c|}{ Total } & \multicolumn{3}{|c|}{$\begin{array}{l}\text { Population connected } \\
\text { with agricultural farm }\end{array}$} & \multicolumn{3}{|c|}{$\begin{array}{c}\text { Population not } \\
\text { connected } \\
\text { with agricultural farm }\end{array}$} \\
\hline & total & males & females & total & males & females & total & males & females \\
\hline \multicolumn{10}{|c|}{$2002 a$} \\
\hline Total & 11.512 & 5.692 & 5.820 & 6.729 & 3.396 & 3.333 & 4.783 & 2.296 & 2.487 \\
\hline $\begin{array}{l}\text { Economically active } \\
\text { population }\end{array}$ & 6.329 & 3.552 & 2.777 & 4.035 & 2.269 & 1.766 & 2.294 & 1.283 & 1.011 \\
\hline Employed & 5.078 & 2.892 & 2.187 & 3.495 & 1.971 & 1.523 & 1.584 & 920 & 663 \\
\hline Unemployed & 1.251 & 660 & 590 & 540 & 298 & 243 & 710 & 363 & 348 \\
\hline $\begin{array}{l}\text { Economically } \\
\text { inactive }\end{array}$ & 4.916 & 2.012 & 2.904 & 2.589 & 1.077 & 1.512 & 2.326 & 935 & 1.392 \\
\hline \multicolumn{10}{|c|}{ 1Q 2017} \\
\hline Total & 12.171 & 6.030 & 6.142 & 3.826 & 1.973 & 1.853 & 8.345 & 4.056 & 4.289 \\
\hline $\begin{array}{l}\text { Economically active } \\
\text { population }\end{array}$ & 6.883 & 3.967 & 2.915 & 2.581 & 1.502 & 1.079 & 4.301 & 2.465 & 1.836 \\
\hline Employed & 6.472 & 3.735 & 2.737 & 2.493 & 1.457 & 1.035 & 3.979 & 2.278 & 1.701 \\
\hline Unemployed & 411 & 232 & 179 & 89 & 45 & 44 & 322 & 188 & 135 \\
\hline $\begin{array}{l}\text { Economically } \\
\text { inactive }\end{array}$ & 5.289 & 2.062 & 3.227 & 1.245 & 471 & 774 & 4.043 & 1.591 & 2.453 \\
\hline
\end{tabular}

${ }^{a}$ The distribution does not take account of people with an undefined status in the labour market.

Source: Labour force survey in Poland (2003); Central Statistical Office, Warsaw; Labour force survey in Poland, $1 Q 2017$ (2017); Central Statistical Office, Warsaw

who manage the farmers' households (despite their actual involvement in farm management); the women's longer average life expectancy (i.e. their higher share in the group of persons of retiring age); and the popularity of the traditional family model in rural areas where women run the households and raise children while the responsibility of men is to earn a livelihood for their families (Kolodziejczak and Wysocki, 2015). Note also that for many women, it is economically unviable to take up a job. This means cases where the expected income is lower or slightly higher than the costs involved in taking up the job. After considering the increase of living costs related to employment; children care; time lost; and the partial loss of social benefits, it may turn out that the woman's job fails to provide any material benefits for the household.

\section{Conclusions}

1) Polish rural areas have a significant population potential and strong labour resources. Over time, their potential will become increasingly important for the entire country, especially considering the progressing urban depopulation.

2) The reasons behind the growth of rural population were the higher demographic growth rate in rural areas compared to cities, and the progressive suburbanization of areas located next to big urban centres. The above does not mean the perpetuation of a typically rural and agricultural nature of rural areas. Neither does it protect the country's poorest and remotest territories against depopulation. Because of suburbanization, some of the rural residents are commuters professionally linked to cities. For them, rural areas mean a place of residence where they can find peace and better quality of living than in cities they migrated from. 
3) In the next years covered by this study, the urban and rural population's professional situation was steadily improving. This was reflected by the consistent increase of the economic activity rate and employment rate, and by the declining unemployment rate.

4) At the beginning of the study period, the rural population demonstrated slightly higher economic activity rates than the urban population. Over time, as the economy was getting better, that difference was reduced to zero. A similar reduction of disparities may be observed when it comes to employment rates. The matter of major importance for the growth of employment and reduction of unemployment was the growing number of jobs resulting from economic development following Poland's accession to the European Union.

5) Usually, the farming population demonstrated higher employment ratios and lower unemployment levels. Also, they were less vulnerable to economic deactivation than nonfarmers. Note, however, that a part of the farming population could stop their work with no detrimental effects on production outcomes. This means hidden unemployment which tends to decrease over time as the number of non-agricultural jobs grows.

6) In the study period, women had a lower share in the group of employed rural residents than men. No considerable changes in this respect occurred between 2002 and 2016. The general improvement of the labour market situation on a countrywide basis enabled a clear increase of the number and share of employed persons. However, as regards women, economic inactivity continued to be the main problem.

\section{Acknowledgments}

The paper is funded by National Science Centre within the MINIATURA research project No. NCN DEC-2017/01/X/HS4/00565, titled "Determinants of Economic Activity of the Rural Population in Poland. Opportunities to reduce hidden unemployment in agriculture" ("Determinanty aktywnosci ekonomicznej ludnosci wiejskiej w Polsce. Mozliwości redukcji bezrobocia ukrytego w rolnictwie").

\section{Bibliography}

1. Aktywnosc ekonomiczna ludnosci Polski (Labour force survey in Poland) (2003). GUS, Warszawa.

2. Aktywnosc ekonomiczna ludnosci Polski I kwartal 2017 (Labour force survey in Poland 1 quarter 2017) (2017). GUS, Warszawa. p. 180.

3. Begg, D., Fischer S., Dornbusch R. (2002). Ekonomia (Economics) t.2. PWE, Warszawa.

4. EUROSTAT. Retrieved: http://www.europa.eu Access: 20.01.2018.

5. Frenkel, I. (2003). Ludnosc, zatrudnienie i bezrobocie na wsi. Dekada przemian (Population, employment and unemployment in the countryside. A decade of changes). Inst. Rozw. Wsi i Roln. PAN, Warszawa.

6. Frenkel, I. (2013). Zatrudnienie i struktura dochodow w gospodarstwach rolnych w latach 2005-2010 (Employment and structure of income in farms in 2005-2010). Inst. Rozw. Wsi i Roln. PAN, Warszawa.

7. Kajdanek, K. (2011). Suburbanizacja w Polsce - pejzaz spoleczno-przestrzenny (Suburbanization in Poland - a socio-spatial landscape), Przeglad Socjologiczny, 2-3(60), pp. 303-320.

8. Karwat-Woźniak, B., Chmielinski, p. (2013). Ludnosc wiejska oraz jej aktywnosc zawodowa i sytuacja na rynku pracy (Rural population and its professional activity and situation on the labour market). (In:) Rynek pracy wobec zmian demograficznych Nr 1/2013. Kielkowska M. (red.). Wyd. Instytut Obywatelski, Warszawa.

9. Kolodziejczak, W. (2011). Sytuacja zawodowa wiejskiej ludnosci rolniczej i bezrolnej w latach 2002 i 2010 (Professional situation of the agricultural and rural landless population in the years 2002 and 2010). Roczniki Naukowe SERiA tom 13, z. 3, Wyd. Wies Jutra Warszawa-Poznan-Wroclaw. pp. 133-137.

10. Kolodziejczak, W. (2016). Nadwyzka zatrudnienia w polskim rolnictwie - projekcja na tle panstw Unii Europejskiej (The Surplus of Employment in Polish Agriculture - A Simulation Against the European Union Countries). Zeszyty Naukowe SGGW w Warszawie Problemy Rolnictwa Swiatowego, t. 16(31), z. 1, pp. 129141.

11. Kolodziejczak, W., Wysocki, F. (2015). Determinanty aktywnosci ekonomicznej ludnosci wiejskiej w Polsce (Determinants of economic activity of the rural population in Poland). Wyd. UP w Poznaniu, Poznan. p. 199. 
12. Krynska, E. (2006). Zasoby pracy w Polsce - stan obecny i perspektywy. Starzenie sie ludnosci i zasobow pracy. Konsekwencje i sposoby ich ograniczania (Labour resources in Poland - current status and prospects. Aging of the population and labour resources. Consequences and ways to limit them). EQUAL, Lodz.

13. Pawlak, K., Standar, A., Kolodziejczak, M., Kolodziejczak W. (2015). Bezposrednie inwestycje zagraniczne w wojewodztwie wielkopolskim, Raport z badania 2015 (Foreign direct investment in the Wielkopolskie voivodship, Research report 2015), Wyd. UP w Poznaniu. p. 55.

14. Prognoza ludnosci Polski na lata 2008-2035 (Population projection for Poland 2007-2035) (2007), GUS, Warszawa.

15. Prognoza ludnosci Polski na lata 2014-2050 (Population projection 2014-2050) (2014). GUS, Warszawa. p. 167.

16. Rocznik Statystyczny Rzeczpospolitej Polskiej (Statistical Yearbook of the Republic of Poland) (2003). GUS, Warszawa.

17. Sobolewska-Wegrzyn, B. (2012). Zmiany aktywnosci ekonomicznej ludnosci wiejskiej w latach 2001-2011 (Changes in Economic Activity of the Rural Population 2001-2011). Barometr Regionalny nr 4(30), pp. 3952.

18. Socha, M., Sztanderska, U. (2002). Strukturalne podstawy bezrobocia w Polsce (Structural foundations of unemployment in Poland). Wyd. Nauk. PWN, Warszawa. P.339.

19. Tyrowicz, J. (2011). Histereza bezrobocia w Polsce (Hysteresis of unemployment in Poland). Wydawnictwa Uniwersytetu Warszawskiego, Warszawa. p. 239. 